\title{
Malaysia's Education Policies and The LaW OF UNINTENDED CONSEQUENCES
}

\author{
Kee-Cheok Cheong ${ }^{\mathrm{a}}$ \\ University of Malaya \\ Christopher Hill \\ British University, Dubai \\ Yin-Ching Leong \\ HELP College of Arts and Technology
}

\begin{abstract}
Since gaining independence in 1957, the Federation of Malaya and now Malaysia has implemented education policies to broaden access, to unify an ethnically diverse population through a common curriculum and language, to enable the disadvantaged to catch up through affirmative action, and to build human capital as the country seeks to become an advanced country in the face of globalization. While some policies, such as enhancing access have achieved their objectives, others, such as unification and development of a national identity, have not. No less important are the unintended consequences of these policies. While some, like the expansion of private higher education and transnational higher education, have been a boon to Malaysian education, others, such as ethnic polarization in education, have been damaging. Some of these consequences, while unintended, have not been unexpected.
\end{abstract}

Keywords: Malaysia, education policy, affirmative action, national unity, ethnic stratification

\section{Introduction}

All actions, undertaken by whoever, have consequences. These consequences may be as intended by whoever takes the action, or unintended by them. Intended consequences are generally beneficial to the party taking the action or its target group. Unintended consequences, however, can be positive, benign, or negative.

Among the many specific actions taken, those by economists and governments are particularly salient. Economists advise actions that can affect the economic wellbeing of many, while governments have the mandate to enact policies that affect those under their jurisdictions. Little wonder, then, that the so-called law of unintended consequences is typically defined with specific reference to the latter actors. Thus Norton (2008) defined it as: "The law of unintended consequences ... is that actions of people-and especially of government-always have effects that are unanticipated or unintended."

What may be the causes of unintended consequences? Merton (1936) cited, among others, ignorance, analytical error, vested interests, basic values, and self-defeating prophesy. Equally common are the need to satisfy multiple objectives, the failure of assumptions to apply to the situation at hand, and to match policy rhetoric with action on the ground. These causes would arouse limited interest were it not for the magnitude of potential impact some actions bring about, especially if the consequence turns out to be perverse. Since policy seeks in principle to do good, a perverse consequence can prove extremely damaging for the country and its citizens.

The Malaysian education system is particularly worthy of consideration because it is subject to many of the factors that render unintended consequences likely, and even inevitable. First, it is made to satisfy multiple objectives, including universal access and affirmative action, of which educational

a Correspondence can be directed to: keecheok1@yahoo.com 
excellence is just one, arguably not even the most important. Second, education policy is often based on assumptions such as the ability of the system to produce internationally competitive graduates with, at best, a second-rate command of English. Third, annual examination results conducted by the education authorities that are, for years, at variance from those from international benchmark assessments, which suggests that, for whatever reason, little effort has been made to investigate, let alone cure, the gap to bring Malaysian standards on par with international benchmarks.

This paper shows that the unintended consequences of the implementation of Malaysia's education policies have been substantial. While some consequences do elicit a positive response, the overall assessment must be that they have been mostly negative in nature.

To recognise what consequences are unintended, it is important to identify what are intended. This is done in the next section, in which the country's education objectives since independence are highlighted. In the sections that follow, each of these intended consequences are analysed in the chronological order the policy objective appeared and with respect to whether it did materialise.

\section{Malaysia's Education Objectives and Policies}

Malaysia's education policies have evolved over a period of half a century, as they responded successively to a shifting national context and external circumstances. Rao (2009) identified three major phases of education policy agendas. The first phase dated from independence as the Federation of Malaya in 1957 until the introduction of affirmative action under the New Economic Policy (NEP) in 1971. The second phase, lasting about two decades from 1970 to the 1990 s, covered the progressive, yet more aggressive application of the NEP to education. This was a period in which the intensification of NEP implementation across sectors occurred and the state took on a progressively larger role. The 1985 recession however saw the partial retreat of the state and the adoption of more liberal policies. Together with the growing impact of globalisation and the attendant need for international competitiveness, the third phase began. In this latest phase, emphasis is on nurturing human capital for Malaysia to become a "knowledge economy" and achieve "Vision 2020", was a strategic objective introduced by former Prime Minister Mahathir Mohamad during the tabling of the Sixth Malaysia Plan in 1991. The vision calls for the nation to achieve industrialised nation status by the year 2020 .

The first phase was defined by the Razak Report, which appeared just before independence (1956) and the Rahman Talib Report in 1961. In both reports, the objective of building a national identity was emphasised as an education objective (Rao, 2009). In the Razak Report, this was to be achieved through a standardised syllabus for both primary and secondary schools and both Malay and English were to be compulsory subjects. It was emphasised that: "The ultimate objective of education policy in this country must be to bring together the children of all races under a national education system in which the national language (Malay language) is the main medium of instruction" (Mohammad Zaini 2014, p.138). The Rahman Talib Report also emphasised the use of Malay as a medium of instruction. These two reports formed the basis of the Education Act, 1961, the passage of which saw the implementation of the national education system in which the medium of instruction in secondary schools was restricted to either English or Malay.

A second theme of education policy was to equalise access to education for the disadvantaged Malays, in essence, the beginning of affirmative action. Only Malay-medium schools were tuition fee-free, with fees also largely waived for Malays in English-medium schools. Most government scholarships also went to Malays who, by virtue of these scholarships, could more easily secure entry to state universities (de Tray 1984, p.2). A subtheme of affirmative action was to increase access to education to ultimately achieve universal education.

The second phase was dominated by the launch and implementation of the New Economic Policy (NEP), the outcome of racial riots in 1969, and applied to education. As earlier indicated, the roots of this policy were to be found well before these riots; in the Barnes Committee's Malay education recommendation of 1951 which stated as its overarching objective to "enable the Malay 
community to occupy its rightful place in the mixed society of Malaysia" (Mohamad Zaini 2014, p.139). The NEP in education was manifested by the imposition of quotas and scholarships for university enrolment. Indeed, Lee (2013) argued that government scholarships were awarded and loans granted on a purely ethnic-based and income blind basis.

The imposition of the NEP did not signify the wholesale abandonment of using language to build a national identity. Post-1969, English schools were converted to Malay medium, the universities being the last to convert by the mid-1970s. In converting English schools to the Malay medium, the government expected that the move would promote shared experiences in elite formation with Malay linguistic and cultural symbols. This educational language policy would convey a sense of belonging so that "non-Malays belong to Malaysia but that Malaysia belongs to the Malays" (Rudner 1977, p.68).

To the extent that education is the pathway to poverty reduction and social mobility, nationbuilding and affirmative action are not necessarily contradictory goals. The extent of education inequality, whether expressed through enrolment rates, years of schooling, and the selection of disciplines in tertiary education, needs to be addressed if Malaysia is to move forward as a unified nation. The use of language as a unifier also continued under this period, with the phasing out of English language as a medium of instruction in favour of Malay language (Puteh, 2010). However, achieving national unity while accommodating ethnic diversity remains a fine balancing act. Of even more relevance is how to assuage the feelings of the communities at the wrong end of affirmative education.

The third phase that began in 1990 reflected a more competitiveness-based approach to education that coincided with the launch by then Prime Minister Mahathir Mohamad of his Vision 2020, with its objective of Malaysia becoming a high-income country by the year 2020. Dubbed by Rao (2009) as the "globalisation era", it followed shortly after a recession forced upon Malaysia the retreat of the role of the state (Thillainathan and Cheong, 2016). A more neo-liberal approach enunciated by (former) Prime Minister Mahathir Mohamad was reflected in his statement: “... globalisation is about competition, the competition of the market place. It is about the dominance of the most efficient" (Mahathir 2002, p.13).

Towards this end, considerable emphasis is placed on using education to build human capital towards achieving a "knowledge economy" (Lee, 1997). This emphasis on competitiveness would appear to require some pull-back of affirmative action. Thus, at least lip service was given to "meritocracy" in education. In reality, this was illusory as quotas were not relaxed (Rao 2009, p.7).

Non-Malay anxieties regarding their lack of access to public universities were indeed assuaged with the passage of the Private Higher Education in which private tertiary education was recognised for the first time. And shortly after, the government proclaimed its objective of turning Malaysia into an international education hub. Yet it must be remembered that this policy represents not a proactive but a reactive stance, a response to the large number of students completing secondary schools that public universities were unable to cater for.

Underlying each policy objective and shift is the strong hand of the federal government, which saw fit to control and to take the lead in every aspect of education from admission to curriculum in schools to senior appointments and the nature of discourses in public universities. Even when the sector opened up to private education, it was subjected to regulation, more tolerated than welcomed, and was seen by the government's scant efforts to tap its potential. It is hardly surprising then that Niaz (2014), in his critique of this mindset, argued: "The Malaysian government should look to civil society for support in strengthening the nation's education system... Civil society needs to bring important issues to the government's attention as well as get local communities to voice their demands for quality education."

Thus, over the course of half a century, several policy priorities have been articulated that assumed prominence at different times. Whether these have been congruent remains a matter of contention. It may be argued, for instance, that the arrival of the NEP overshadowed earlier efforts to build national unity and identity. Similarly, it has been argued that the more neoliberal policy stance since the 1990s has blunted its momentum (Lee, 1997; Lee H.A., 2012). Still, there can be no 
doubt that affirmative action continues to provide the subtext in all policy discussions. The question that needs to be asked is the extent to which these objectives have been realised.

\section{Education and National Unity}

Since colonial times, education in Malaysia has been defined by ethnic stratification and implemented through ethnic inclusion and exclusion. Indeed, the entire education process from primary to tertiary education has relied on ethnic markers, while education policies are also framed in ethnic segregation terms (Hazri and Nordin, 2010), Central to this segregation is affirmative action embodied by the NEP. In such a situation, it is to be expected that the beneficiaries of ethnic inclusion, the Bumiputera ( or 'sons of the soil', referring to the Malay race and other indigenous group in Sabah and Sarawak), view efforts to create a national identity very differently from those who suffered ethnic exclusion, the ethnic Chinese and Indians. Reflecting the former view, Mohamad Zaini (2014, p.141) concluded that "... the policy of preferences ... does not aim at ethnic dominance or supremacy (but) ... merely seeks to overcome the historical backwardness of the Malays." Reflecting the latter view, Ting (2013, p.5) saw the government's stated nation-building goal as "a thinly veiled state project to assimilate minorities."

The story of this segregation began in colonial times and continued after Malaya became independent in 1957. A primary school system that had distinct vernacular language streams in addition to schools with Malay and English as media of instruction was blamed on colonial divideand-rule policies before independence and rationalised as the need to reconcile multi-ethnic demands after independence (de Michaeux, 1997).

Yet, policy and institutional factors account for only part of the segregation story. In addition and complementary to the NEP, Raman and Tan (2010) attribute this segregation to enrolment choices. This is amply illustrated by Table 1 below which shows that ethnic Chinese parents sent their children overwhelmingly to Chinese schools. This choice, according to Lee H.G. (2012, p.175), stemmed from their belief of marginalization by state policies, repeated proclamations of ketuanan Melayu (Malay preeminence), ethnocentric attitudes of a largely Malay teaching and administrative staff that sometimes found their way to the media, and perceived Islamization of national schools.

Table 1. Ethnic Chinese Student Enrolment in Primary Schools, 1973 - 2005

\begin{tabular}{|c|c|c|}
\hline Year & $\begin{array}{c}\text { \% Chinese students in SRJK-C } \\
\text { (Government Chinese Primary School) }\end{array}$ & $\begin{array}{c}\text { \% Chinese students in SRK } \\
\text { (Government Malay Primary School) }\end{array}$ \\
\hline 1973 & 82.4 & 17.6 \\
1978 & 88.2 & 11.8 \\
1995 & 89.0 & 11.0 \\
1998 & 90.6 & 9.4 \\
1999 & 90.9 & 9.1 \\
2005 & 94.7 & 5.3 \\
\hline
\end{tabular}

Source: Lee H.G. (2012, p.174)

At secondary school level, Chinese parents have greater acceptance of national schools, but more so because most Chinese medium schools have complied with the government's language policy, as shown in section 4, in order to secure continued government funding (Lee H.G. 2012, p.175). Even with their conversion to "National Type Chinese Secondary Schools", however, their "internal culture remains identifiably Chinese and the schools have retained close links with the local Chinese community" (Raman and Tan 2010, p.120) which still regards them as "Chinese schools". To make things worse, a number of Chinese-medium schools elected not to receive government funding and maintained their Chinese-based curriculum, and instead obtained their funding from 
the ethnic Chinese community. These are the so-called "Independent Chinese Secondary Schools" (ICSS) (Raman and Tan 2010, p.122). While these schools were eventually included in the national school system in 1996, they received no financial assistance, and its United Examinations Certificate (UEC) was not recognised by the government, meaning students coming out of ICSS cannot enrol in public tertiary institutions. (Lee H.G. 2012, p.175) estimated that although the majority of ethnic Chinese students are enrolled in national-type Chinese secondary schools (128, 000 in 2002), a significant minority $(54,000$ to 60,000 since 1990) has opted for the ICSS. Thus government efforts to integrate Chinese-medium schools into the national system have been unsuccessful.

No less damaging for national integration, thanks to the NEP, are the schools set up exclusively for the Bumiputera community. These are the fully residential schools, the junior science colleges established by the Majlis Amanah Rakyat (MARA - Council of Trust for the Indigenous People), and the Islamic religious schools (Raman and Tan 2010, pp.121-122)

It is not only at the school level that education policy has had consequences opposite to those intended. Pathways from school to higher education are also ethnically segregated. Thus, the Matriculation programme of public higher education institutions (HEIs) is largely the preserve of Bumiputera, and completion of the programme almost always resulted in admission to public HEls. While Bumiputera study for the Higher Religious Certificate, non-Bumiputera study for the competitive Sijil Tinggi Persekolahan Malaysia (STPM) or for university foundation programmes. Those non-Bumiputera students who study for their A-levels are not eligible to enter public HEls, but, it should be noted, have already decided to pursue higher education overseas or in foreign university programmes in local private HEls. Rao $(2009, \mathrm{p} .12)$ also noted that remedies against education injustices are also on ethnic lines. Students of a particular ethnicity with complaints against education placements or awards have to appeal to the ethnic-based political parties that purportedly represent their community.

In higher education itself, a rapidly rising demand for tertiary education as students complete their secondary education and insufficient places in public universities to meet this demand, together with quotas as tools of exclusion for non-Bumiputera students have led to a surge in the number of private HEls. Students enrolled in these private HEls initially consisted primarily of non-Bumiputera denied places in public HEls and unable to afford an education overseas. However, as these private HEls brought in foreign academic partners through a variety of cooperative arrangements, as shown in section 6, and English became necessarily the language of instruction, they became institutions of choice of the non-Bumiputera despite the much higher tuition fees they charge. These institutions' attraction also lay in the fact that their presence allowed students who, voluntarily or otherwise, remained outside the national school system to progress all the way to tertiary education. Meanwhile, fortified by quotas up to $100 \%$ in some institutions (for example, Universiti Teknologi MARA, International Islamic University and Islamic Science University), public HEls enrolled a majority of Bumiputera students. The rise of private higher education, institutionalised by the Private Higher Education Institutions Act of 1996, has thus produced a tertiary education system with private and public sectors running on parallel tracks, with no links between them, either via study pathways or through staff transfer. The strengths and weaknesses of each system are thus locked in, with no cross-fertilization of ideas or human capital.

This segregation has consequences beyond higher education itself. Employer perceptions of graduate employability have been found to be based on the type of $\mathrm{HEI}$ from which students graduated. Cheong et al. (2015) found that employers viewed foreign graduates as being of the highest calibre, followed by graduates from local campuses of foreign universities, other graduates of transnational education, graduates of private HEls, and graduates of public HEls in that order. Although recognizing the strengths and weaknesses of each type of graduate, employers and their recruitment preferences are undoubtedly affected by their perceptions. 


\section{Language as a Unifier}

The use of language as an instrument of unification in a country with diverse ethnic groups and multiple languages/dialects being spoken has ample precedent, examples being Mandarin in China and Bahasa Indonesia in Indonesia. In the case of Malaysia, Malay can stake a strong claim as a unifying language, fulfilling two key conditions of being spoken by a majority of the population and related to other languages in the region, although not the third - being politically neutral (Nida 1975, pp.160-161). But it can have the opposite effect, as Kelman (1971, p.21) warned.

Unfortunately for Malaysia, in the context of a society defined by ethnic stratification and reinforced by policies of ethnic inclusion and exclusion, it is the latter impact that prevailed. Dissatisfaction with the language policy can be found from the very beginning. As already indicated, the system inherited from British Malaya had consisted of vernacular schools at the primary level coexisting with national schools in which the medium of instruction was either Malay or English. By mandating first the use of English and Malay and then Malay in all secondary schools, vernacular primary schools “... were dead ends, which failed to prepare students either for any form of further education available or officially recognised in Malaysia or for employment in other than small-scale ethnic enterprises" (Snodgrass 1980, pp.250-251).

Further, by forcing through the use of Malay in all secondary schools, Chinese-medium secondary schools had to comply or risk losing government funding. Even with their diminished use of Chinese, however, they were considered by ethnic Chinese parents as "Chinese schools". And, as indicated earlier, a small number of Chinese-medium schools defied the government's language policy by resorting to non-government funding.

Beyond the tensions created by exclusion/inclusion, Wong (1981) argued that there was a fundamental difference in non-Bumiputera and Bumiputera views of the education system. While the former tend to view the educational system as the place for open competition in which social and economic rewards are bestowed on the basis of achievement, the latter perceive it as the instrument which accords them preferential acceleration of mobility without necessarily having to compete with the non-Bumiputera. Thus, although not what the policy-makers anticipated, such an outcome is hardly surprising. This difference in perception epitomises what Chai (1977, p.59), commenting on the education policies pursued during the first decade of the NEP, concluded that it was "ironic that the twin interlocking instruments of nation building, language and education, have divided rather than united Malays and non-Malays."

After 1990, with globalisation's benefits widely advertised, and Vision 2020 proposed by then Prime Minister Mahathir as a national strategy, the role of the English language was resurrected as complementary, if not competitive, with the national language policy. The next milestone for language policy came when the government permitted the use of English for teaching technical subjects at the post-secondary level when the 1996 Education Act was passed. In the same year, with the government objective of turning Malaysia into an international education hub, the passage of the Private Higher Education Institution Act expanded the use of English as the language of instruction to twinning programmes and offshore campuses of foreign universities (Puteh 2010, p.195). Although the primacy of the Malay language was safeguarded in the 1996 Education Act requiring private HEls to have the Malay language as a compulsory subject, this stipulation was more often honoured in the breach than observed

However, pressure to reintroduce the English language into the school curriculum also came from within. Subject to no language control, the private sector was also a lobby for English language competency (Gill, 2005; Hariati and Lee, 2011). As pressure to achieve competence in English continued to build, the Ministry of Education reintroduced, after a lapse of over two decades, the teaching of mathematics and science in English in 2003. This move, although opposed by both Malay nationalists and Chinese educators for once united by their fear that the importance of their respective languages would be eroded (Lee H.G. 2012, p.178), was eventually undone not by these opponents but by weaknesses in the initiative's conceptualization and implementation $(G 25,2015)$. 
Thus, the objective of the use of the Malay language as a unifier had to first deal with the mistrust of the minority communities who associated it with the NEP and then with the even more powerful economic forces of globalisation and technological advance. In the end, the former undermined this objective while the latter diluted it. Given the ethnic context of Malaysian society, with the NEP sharpening the divide, and the reality of employability at the micro-level and economic advance being driven by national competitiveness at the macro-level, the ultimate ineffectiveness of this objective is hardly surprising.

\section{Education Access and Affirmative Action}

The government's policy focus on education, backed by fiscal resources, has greatly increased access to education, with the NEP ensuring that disadvantaged Bumiputera were no longer educationally handicapped. The United Nations Development Programme (UNDP 2005, p.22) confirmed Malaysia's achievement of universal primary education (Millennium Development Goal 2) by 1990. In secondary education, net enrolment rates have climbed to over $80 \%$ for lower secondary education and over $70 \%$ for upper secondary education by 2003 (UNDP 2005, p.71). These impressive results reflected the government's drive towards massification of education from what was an elite system that favoured English schools in urban areas.

Credit for increasing education access goes to the application of the NEP to this sector. Since its launch in 1971, the NEP has explicitly driven, or was the subtext for, all education policies. Its most visible consequence applied to education through quotas for students, teachers, institutions and student loans has been the increased education access for the majority Bumiputera community and hence for the population overall. This is highly evident from the growing numbers of Malay students enrolled and their rising share in total enrolment.

But this success has been achieved not without cost. Arguably the most significant unintended and perverse consequence is the deterioration in education quality. While examination results for schools show better performances year after year, Malaysia has been falling behind in international benchmark tests of mathematics and science (the Organization for Economic Cooperation and Development (OECD)'s Programme for International Student Assessment, PISA, and the Trends in International Mathematics and Science Study, TIMSS) (Table 2). This decline is alarming in that not only is Malaysia losing ground comparatively but also absolutely - test scores have been falling, in both tests, below the average for all participating countries. This deterioration in performance is out of step with the multiple awards of 'distinctions' to students in locally conducted examinations. This deterioration in school performance has implications for the quality of the country's higher education, to which a proportion of students from secondary education would progress.

Table 2. Malaysia's Test Scores in International Tests TIMSS and PISA, 1999 to 2011

\begin{tabular}{|c|c|c|c|c|c|c|}
\hline \multirow{2}{*}{$\begin{array}{c}\text { Country/Skill } \\
\text { Tested }\end{array}$} & \multicolumn{4}{|c|}{ TIMSS } & \multicolumn{2}{|c|}{ PISA } \\
\hline & 1999 & 2003 & 2007 & 2011 & 2009 & 2012 \\
\hline $\begin{array}{l}\text { Mathematics } \\
\text { Malaysia } \\
\text { Korea, Rep. } \\
\text { Singapore } \\
\text { Taiwan }\end{array}$ & $\begin{array}{l}519 \\
578 \\
604 \\
585 \\
\end{array}$ & $\begin{array}{l}508 \\
589 \\
605 \\
585 \\
\end{array}$ & $\begin{array}{l}474 \\
597 \\
593 \\
598 \\
\end{array}$ & $\begin{array}{l}440 \\
613 \\
611 \\
609 \\
\end{array}$ & $\begin{array}{l}404 \\
546 \\
562 \\
543 \\
\end{array}$ & $\begin{array}{l}421 \\
554 \\
573 \\
560 \\
\end{array}$ \\
\hline $\begin{array}{l}\text { Science } \\
\text { Malaysia } \\
\text { Korea } \\
\text { Singapore } \\
\text { Taiwan }\end{array}$ & $\begin{array}{l}492 \\
549 \\
568 \\
569\end{array}$ & $\begin{array}{l}510 \\
558 \\
578 \\
571\end{array}$ & $\begin{array}{l}471 \\
553 \\
567 \\
561 \\
\end{array}$ & $\begin{array}{l}426 \\
560 \\
590 \\
564 \\
\end{array}$ & $\begin{array}{l}422 \\
536 \\
542 \\
520 \\
\end{array}$ & $\begin{array}{l}420 \\
538 \\
551 \\
523 \\
\end{array}$ \\
\hline
\end{tabular}

Sources: PISA (https://www.oecd.org/pisa/) and

TIMSS (https://nces.ed.gov/timss/) 
How can this deterioration be explained? Tan (2012) points to the education system allowing academically weak students to progress rather than addressing the source of their handicap as one major reason. The NEP has certainly had a hand in precipitating this state of affairs. As has already been described, in seeking not only to equalise access to education (places for Bumiputera secondary school students) but also to equalise outcomes (admission to HEls), the government set up parallel tracks in the secondary school system, with one track, mainly for Bumiputera, virtually guaranteed admission to HEls (Cheong et al. 2011, p.177; Loo 2007, p.223; Pak, 2013). Other schools/colleges set up for Bumiputera students, such as residential schools and MARA junior science colleges also allow their students to bypass the more rigorous STPM route to HEI admission. More broadly, Lee and Nagaraj (2012, pp.224-225) pointed to pedagogy and curricula that emphasised rote learning and paid little attention to the diverse needs of students.

Another unintended consequence, stemming from this decline in the quality of the national school system, is the growing popularity of Chinese independent secondary schools, which have become the schools of preference for many parents for their children. Despite the higher fees they charge, these schools have had "to turn away thousands" (Kong, 2013). Kong (2013) cited the example of Kuen Ching Independent Secondary School in Kuala Lumpur receiving 1,681 applications for its 800 new places, and of four other Chinese independent secondary schools having to institute entrance examinations due to the strong demand for places. Sporting physical facilities often superior to those of national schools, these schools have seen a status-reversal from the time they were regarded as schools of last resort to national schools using English as the medium of instruction. That their enrolment continues to rise year after year speaks to their growing popularity (The Star, $31^{\text {st }}$ January 2016).

It is arguably in higher education that the NEP has made the greatest impact. As Rao (2009, p.5) highlighted some striking results of the early implementation NEP applied to higher education in the 1970s:

Within a few years of the implementation of the policy of quotas, nearly three-fifths of all students enrolled in higher education were Malays and only one third were Chinese. More than half the Chinese applicants for University admissions were turned down. Overall, there was a steady increase of Bumiputera students in public institutions of higher education and a steep decrease of Chinese and Indian students.

As in secondary education, these gains in numbers notwithstanding, a perverse impact has been the erosion of standards reflected in Malaysian universities falling in or garnering low international rankings. Cheong et. al (2011, p.173) recorded the University of Malaya's ranking in 2007 to be as low as 247 in the Quacquarelli Symonds World University Rankings, well below those of leading universities in the Newly Industrialised Economies and China, with other Malaysian universities even lower. A new Vice Chancellor appointed in 2008 relentlessly drove the university's ranking higher, but he was replaced in 2013. The university's ranking continued to climb, to 133 in 2016, but severe budget cuts in research has cast doubts about its further advance.

Compounding the challenges public HEls had to face, it is in higher education that the NEP has resulted in the greatest ethnic exclusion. This is summarised by Mukherjee et. al $(2011$, p.102):

The public university admissions quota system overwhelmingly supported one ethnic group the Bumiputeras... overall Chinese and Indian representations were lower than their proportion in the population. The implementation of an admissions policy based on meritocracy has not changed the picture much - in fact, the proportion of Bumiputeras has continued to increase. Government scholarships have financed a small segment of Chinese and Indian students but again not in proportion to their population.

They cite Bumiputera enrolment in public HEls between 2005 and 2008 to be over $80 \%$ (Mukherjee et al. 2011, p.41) and their share of scholarships to local public HEls and foreign HEls for the period $2000-2008$ at $87 \%$ and $73 \%$ respectively (Mukherjee et al. 2011, p.92). 
This ethnic exclusion has produced another unintended consequence, this time, for higher education. This is the rise of private sector tertiary education to cater to the unmet demand for tertiary education. That the government was not a willing partner in this development is clearly seen by its initial refusal to allow private HEls to award degrees, and even after it did, with the passage of the Private Higher Education Act in 1996, subjected only them, not public HEls, to quality audits by the Lembaga Akreditasi Negara (LAN - National Accreditation Board). And despite pronouncing its objective of making Malaysia an international education hub, mandated private HEls to end awards, even jointly, of foreign degrees.

Despite these initial hurdles, private sector tertiary education expanded rapidly. Student enrolment in private HEls increased significantly in the last decade (2000 - 2010), from 209,585 in 2000 (Malaysia, 2001) to 484,377 in 2010 (Ministry of Higher Education, 2010), an increase of 131\%. When the decade ended, private HEl students outnumbered their counterparts in public HEls by a ratio of 52.5 to 47.5. This surge forced upon government a change of mind once they saw in this development the benefits of reducing non-Bumiputera disenchantment with the government's NEP-driven education policies, of saving foreign exchange, and of potentially easing the outflow of local talent.

Despite facilitating increased access, the expansion of private tertiary education has its downside in that non-Bumiputera children from poorer families cannot afford the high fees charged. Thus, it may have contributed to an increase in disparity between middle-class and rich and poor non-Bumiputera students. The latter would have been forced to apply to public HEls and take their chances despite the unfavourable odds (Lee H.G. 2012, p.184).

\section{Globalisation, Human Capital Deepening and Transnational Education (TNE)}

Related to the burgeoning of private higher education but also distinct from it is the advent of transnational education (TNE), defined as "all types of higher education study programmes, or sets of courses of study, or educational services (including those of distance education) in which the learners are located in a country different from the one where the awarding institution is based." (UNESCO/ Council of Europe, 2001). The arrival of TNE to Malaysian shores, and with it a novel form of foreign influence in Malaysian education is a direct product of the unintended consequence of private sector higher education growth. Itself an unintended consequence, TNE has been retroactively justified and strategically implemented. The fact that the development of TNE in the country is characterised by an early period of 'wild west' where anything was possible, to subsequent over-regulation before arriving at responsible regulation suggests a pattern of reaction rather than measured response and demonstrates a fundamental lack of understanding by policymakers of where TNE could take the country. This lack of understanding is to be expected given the almost complete absence of detailed knowledge of TNE at the time.

Even if TNE was not harnessed to boost the quality of local education, the entry of foreign tertiary education providers has the positive unintended consequence of providing Malaysia with the opportunity to market itself as a hub for international higher education. The country has also benefited considerably from the income stream this has generated and associated branding/ reputational factors. This in turn has led to Malaysia exporting TNE and becoming a significant TNE player on the global stage.

But TNE also has other unintended consequences, some far from desirable. First, the Private Higher Education Act 1996 states that the medium of instruction is Bahasa Malaysia. With the introduction of TNE, private HEIs operating TNE programmes are required to write to the Ministry of Higher Education for its approval to use English as a medium of instruction. This requirement is not followed as the assumption of approval is taken for granted. Thus TNE has strengthened the use of English in private HEls, sharpening the language divide between public and private HEls. Second, the ethnic imbalance in enrolment between private and public HEls has been made worse by the arrival and expansion of TNE. Third, TNE has reinforced the trend for private higher education to become 
progressively elitist. However, with enrolment high in business, finance and accounting programmes as compared to pure and applied sciences, this does not help the government objective of increasing the share of students pursuing the hard sciences. Finally, in reinforcing the divergences already noted with the rise of private higher education, TNE has further fragmented labour market perceptions. Among graduates from private HEls, employers have come to favour those coming through TNE over those who did not, the former on the basis of their joint/dual degrees and use of English.

Even if these consequences are unintended, some could have been leveraged for the good of the education system as a whole. One area is the use of the English language, as listed above, which has its connections here too. This is the language of instruction and the dynamic and positive perception of local private higher education has been greatly influenced by the evolution and expansion of TNE in partnership with them or in their midst. Issues of quality (perceived and otherwise), recruitment, employability and value have all played a part in the identity of public Malaysian HEls - particularly when compared with foreign providers (Cheong et al., 2015).

Another area in which TNE can be leveraged is to contribute to the objective of producing human capital to compete in a competitive globalised world. When Dr. Mahathir launched Vision 2020, he envisaged that education improvement was to spearhead the drive towards the Vision's achievement. However, the number and share of students opting for science and technology subjects in public HEls were extremely low by international standards. Cheong et. al (2011, p.173) showed that in the mid-2000s, the proportion of Malaysian students studying technical subjects was a paltry $14 \%$, less than half that for Korea and Taiwan, and also much lower than China, India and Singapore. To remedy the situation, the government has promoted the study of science subjects through a host of new institutions like MARA junior science colleges, but to date, not much has changed, leading to the assessment by Chandran et. al $(2005$, p.1) that "with regard to education, R\&D and other fundamental mechanisms to accelerate the process of innovation was still absent in Malaysia." The implementation of another initiative, IBestariNet, to equip all government schools with internet connection and laptops shows how poor planning and execution have jeopardised such efforts and wasted resources (Gryzelius, 2015).

TNE, if involving international universities with technological specializations and expertise, can contribute to remedying this lack of national capability and the government's unsuccessful initiatives. By virtue of their positive perception in the eyes of the public and being not subject to the NEP, they offer an avenue by which the government can reconcile its human capital objective without compromising its NEP goals. Yet by its lack of understanding of TNE and its many instruments, the government has not availed itself of this opportunity.

This failure to leverage off TNE's potential is because compared to private HEls, public HEls have not had the same extent of interaction with foreign universities in the form of TNE. This is the result of an "us vs. them" mentality among public sector officialdom combined with a lack of understanding of the opportunities that TNE offer, as already discussed. Yet, one could argue that the arrival of TNE has impacted public sector higher education. The STAR ranking under the Malaysia Research Assessment (MYRA) is a response to foreign influence and the global ranking system. Unable to compete on the global stage, and unable to look less than when compared to foreigners at home, a system of ranking was implemented that created a new reality and maintained the previous status quo. It would appear that from the public sector perspective, TNE is desired for its ability to fill a market need but rejected for the value system it perpetuates in terms of language capability, international exposure, and employability.

TNE has raised the profile on education in Malaysia and provided opportunities along the way for the introduction of innovative pedagogies, research collaboration and output. But it has weakened the stranglehold the government has over the system through bringing in foreign parties with whom the government is not familiar and who have their own agendas that may be at variance with national priorities. While regulation systems are clearly in place to support and promote national objectives, structures and aims, the TNE system has evolved considerably, and is continuing to 
evolve, both in content, access and outlook. The possibility that regulations are perpetually playing catch-up is very real.

\section{Conclusion}

A first cut in assessing any policy's efficacy is to determine whether its objectives are achieved. In the context of this paper, the education objectives that have been undoubtedly achieved are the greatly expanded access to education, and especially to assist the disadvantaged Bumiputera due to the implementation of the NEP. An implication of this assessment is that achievement of objectives is a positive development and failure to achieve it negative. This is an oversimplification. The NEP has certainly benefited its target clientele, but those subject to ethnic exclusion have been victimised by it. Exogenous developments may also bring pressure to bear on policy. The growing role of globalisation has given impetus to the learning of English and brought on a policy shift, if only partial.

A second cut at assessment is to determine impact. It is also often assumed that meeting objectives implies positive impact. But failure to meet objectives does not signify the absence of impact. Indeed, as the examples of unintended consequences above show, impact can be quite substantial. This impact can be perverse, i.e. when the opposite of what is intended occurs. Or it may emanate from issues related to a particular policy. Thus, the switch to Malay saw a serious decline in English language proficiency at a time when the world looks to English as a universal language. And the failure to meet the rising demand for higher education has spawned a vibrant private tertiary education sector, and with it, TNE. Some unintended consequence may have nothing to do with objectives being met. For example, the successful implementation of the NEP to education has led to a serious decline in the quality of education.

Finally, it should be noted that "unintended" does not mean "unexpected." Where failure to meet objectives is the products of policy contradictions, such an outcome may certainly be expected. And if it is not, policy-makers may be labouring under the wrong assumptions. Thus in the case of the NEP and national unity, Brown $(2005$, p.1) noted:

... the Malaysian regime has sought to resolve the tensions between nation-building and ethnicity through a didactic and pedagogical approach to educational development, which promotes a concept of nationhood that, rather than transcending ethnic allegiances, is explicitly based on ethnic stratification... these 'ethnic citizens' are encouraged to participate in the Malaysian nation uncritically through the virtual worship of development symbols and unquestioning deference to political leadership.

That this assumption is untenable is clear from the fact that unless education is truly "dumbed down", its progress would surely lead to greater critical questioning of that assumption.

\section{References}

Brown, G. (2005). Making Ethnic Citizens: The politics and practice of education in Malaysia. Working Paper No. 23. Centre for Research on Inequality, Human Security and Ethnicity: Oxford University.

Chai, H.C. (1977). Education and Nation Building in Plural Societies: The west Malaysian experience. Canberra: Australian National University.

Chandran, V.G.R., Sundram, V.P.K., Mohamed Hashim, M.K., Zin, I. and Farha, A.G. (2005). Science, technology and innovation in Malaysia: What do the key indicators suggest? Paper presented at the Seminar IRPA, Universiti Teknologi MARA, Putrajaya, 26-27 February.

Cheong, K.C., Hill, C., Fernandez-Chung, R. and Leong, Y.C. (2015). Employing the unemployable: Employer perceptions of Malaysian graduates. Studies in Higher Education, 41(12), pp.22532270. 
Cheong, K.C., Selvaratnam, V. and Goh, K.L. (2011). Education and human capital formation. In R. Rasiah (Ed.), Malaysian Economy: Unfolding Growth and Social Change. Kuala Lumpur: Oxford University Press, pp. 159-184.

de Micheaux, E.L. (1997). The role of education policy in overcoming ethnic divisions and building Malaysia's nation. Paper presented at the Oxford International Conference on Education, Oxford. 11- 15 September.

de Tray, D. (1984). Schooling in Malaysia: Historical trends and recent enrollments. Santa Monica, CA: Rand Corporation for the US Agency for International Development.

Gill, S.K. (2005). Language policy in Malaysia: Reversing direction. Language Policy, 4, pp. 241-260. Group of 25 Eminent Malays (G25). (2015). English Language Issue in Malaysia Revisited. Malaysiakini, July 29. Available at http://www.malaysiakini.com/letters/306589. [Accessed 26 May 2016].

Gryzelius, J. (2015). ICT in Classroom Learning: Exploring the discrepancies between ideal conditions and current Malaysian policy. Policy Ideas No. 18, Institute for Democracy and Economic Affairs: Kuala Lumpur.

Hariati, A. and Lee, Y.M. (2011). Top Jobs Only for Those Who Know the Language Well. The Star, April 10. Available at http://www.thestar.com.my/news/nation/2011/04/10/top-jobs-only-forthose-who-know-the-language-well/. [Accessed 27 May 2016].

Hazri, J. and Nordin, A.R. (2010). Ethnicity and education policy in Malaysia: Managing and mediating the ethnic diversity. Journal of US-China Public Administration, 7(1), pp. 77-87.

Kelman, H.C. (1971). Language as an aid and a barrier to involvement in the national system. In J. Rubin and B.H. Jernudd (Eds.), Can Language be Planned? Honolulu: University Press of Hawaii, pp. 21-51.

Kong, S.H. (2013). Chinese Schools to Turn Away Thousands. The Sun Daily November 5. Available at http://www.thesundaily.my/news/874490. [Accessed 27 May 2016].

Lee, H.A. (2012). Affirmative action in Malaysia: Education and employment outcomes since the 1990s. Journal of Contemporary Asia, 42(2), pp. 230-254.

Lee, H.G. (2012). Education of the Chinese in Malaysia. In H.G Lee and L. Suryadinata (Eds.), Malaysian Chinse: Recent Developments and Prospects. Singapore: ISEAS, pp. 166-192.

Lee, H.G. (2013). Racial citizenship and higher education in Malaysia. In E.T. Gomez and J. Saravanamuttu (Eds.), The New Economic Policy in Malaysia: Affirmative Action, Ethnic Inequalities and Social Justice. Singapore: ISEAS Publishing, pp. 235-261.

Lee, K.H. and Nagaraj, S. (2012). The crisis in education. In H. Hill, S.Y. Tham and M.Z. Ragayah (Eds.), Malaysia's Development Challenges: Graduating from the Middle. Abingdon: Routledge, pp. 213-232.

Lee, M.N.N. (1997). Education and the state: Malaysia after the NEP. Asia Pacific Journal of Education, $17(1)$, pp. $27-40$.

Loo, S.P. (2007). Schooling in Malaysia. In G.A. Postiglione and J. Tan (Eds.), Going to School in East Asia. Westport, Connecticut: Greenword Press, pp. 207-227.

Malaysia. (2001). Eighth Malaysian Plan, 2001-2006. Kuala Lumpur: Government Printers.

Mahathir, M. (2002). Globalization and the New Realities. Kuala Lumpur: Pelanduk.

Merton, R.K. (1936). The unanticipated consequences of purposive social action. American Sociological Review, 1(6), pp. 894-904.

Ministry of Higher Education. (2010). Higher Education Statistics. Available at http://www.mohe. gov.my/web_statistik/. [Accessed 27 May 2016].

Mohamad Zaini, A.B. (2014). Education policy and ethnic relations in Malaysia: The socio-economic perspectives. Journal of Education and Social Research, 4(2), pp. 138-142.

Mukherjee, H., Singh, J.S., Fernandez-Chung, R.M. and Marimuthu, T. (2011). Affirmative action policies in Malaysia's higher education. Washington DC: World Bank.

Niaz, A. (2014). Managing Malaysia's Education Crisis. East Asia Forum, December 5. Available at http://www.eastasiaforum.org/2014/12/05/managing-malaysias-education-crisis/. [Accessed 30 May 2016]. 
Nida, E. (1975). Componential Analysis of Meaning: An introduction to semantic structures. The Hague: Mounton.

Norton, R. (2008). Unintended Consequences. Concise Encyclopedia of Economics. Available at http:// www.econlib.org/library/Enc/UnintendedConsequences.html. [Accessed 17 May 2016].

Pak, J. (2013). Is Malaysia University Entry a Level Playing Field? BBC News September 2. Available at http://www.bbc.com/news/world-asia-23841888. [Accessed 12 July 2016].

Puteh, A. (2010). The language medium policy in Malaysia: A plural society model? Review of European Studies, 2(2), pp. 192-200.

Raman, S.R. and Tan, Y.S. (2010). Ethnic segregation in Malaysia's education system: Enrolment choices, preferential policies and desegregation. Paedagogica Historica, 46(1-2), pp. 117-131.

Rao, S. (2009). Globalization, Affirmative Action and Higher Education Reforms in Malaysia: A Tightrope Walk between Equality and Excellence. The Asian Scholar, 5. Available at http:// www.asianscholarship.org/asf/ejourn/index.html. [Accessed 19 May 2016].

Rudner, M. (1977). The economic, social and political dimensions of Malaysian education policy. In K. Orr (Ed.), Appetite for Education in Contemporary Asia. Canberra: Australian National University, pp. 62-90.

Snodgrass, D.R. (1980). Inequality and Economic Development in Malaysia. New York: Oxford University Press.

Tan, Y.S. (2012). Democratization of secondary education in Malaysia: Emerging problems and challenges of educational reform. International Journal of Educational Development, 32, pp. 53-64.

The Star. (2016). Chinese School Student Numbers Rise. January 31. Available at http://www.thestar. com.my/news/nation/2016/01/31/chinese-school-student-numbers-rise/. [Accessed 27 May 2016].

Thillainathan, R. and Cheong, K.C. (2016). Malaysia's new economic policy, growth and distribution: Revisiting the debate. Malaysian Journal of Economic Studies, 53(1), pp. 51-68.

Ting, H.M.H (2013). Language-in-education policy in Malaysia: Context, implementation and challenges. Presentation at the $4^{\text {th }}$ International Language and Education Conference, Mahidol University, Bangkok, 6-8 November.

United Nations Development Program (UNDP) (2005). Malaysia - Achieving the Millennium Development Goals: Successes and challenges. Kuala Lumpur: UNDP.

UNESCO/Council of Europe. (2001). Code of Good Practice in the Provision of Transnational Education. Riga, 6 June. Available at http://www.coe.int/t/dg4/highereducation/recognition/Code\%20 of\%20good\%20practice_EN.asp. [Accessed May 18 2016].

Wong, Y.C. (1981). The Objectives and Process of Schooling: Perceptions of secondary school leavers, teachers, principals and parents of Kuala Langat district, Selangor, in Peninsular Malaysia. Unpublished Phd Thesis, Institute of Education: University of London. 
